Till frågan om kronans vattenrätt

Author(s): B. H. Dahlberg

Source: Ekonomisk Tidskrift, Årg. 4 (1902), pp. 153-178

Published by: Wiley on behalf of The Scandinavian Journal of Economics

Stable URL: http://www.jstor.org/stable/3437096

Accessed: 23-05-2016 04:29 UTC

Your use of the JSTOR archive indicates your acceptance of the Terms \& Conditions of Use, available at

http://about.jstor.org/terms

JSTOR is a not-for-profit service that helps scholars, researchers, and students discover, use, and build upon a wide range of content in a trusted digital archive. We use information technology and tools to increase productivity and facilitate new forms of scholarship. For more information about JSTOR, please contact support@jstor.org.

The Scandinavian Journal of Economics, Wiley are collaborating with JSTOR to digitize, preserve and extend access to Ekonomisk Tidskrift 


\section{Till frågan om kronans vattenrätt.}

En undersökning angående 1697 års kvarnkommissioner.

\section{Af B. H. Dahlberg.}

Den regel, som bestämt strandägarens rätt till vattenområdet vid stranden, har hos oss alltsedan landskapslagarnes tid varit, att "den äger vatten, som land äger». Strandägaren har med andra ord ägt förfoga öfver vattnet vid stranden $\mathrm{i}$ den mån, denna hans rätt ej $\mathrm{i}$ särskilda afseenden begränsats. I gällande rätt har denna regel kommit till uttryck i I 2 kap. $\$ 4$ jordabalken i I734 års lag, der strandfastigheters ägogränser i vattnet bestämmas, samt i $\$ I af kongl. förordningen den 30 december I 880 om jordägarens rätt öfver vattnet å hans grund, där det föreskrifves, att en hvar äger tillgodogöra sig det vatten, som å hans grund finnes, $\mathrm{i}$ den mån ej annorledes stadgats.

Ej sällan har emellertid den uppfattningen framträdt, att strandägarens på angifna sätt bestämda rätt icke sträckte sig till alla vattendrag inom landet, utan skulle äganderätten till åtskilliga mer betydande vattenområden tillkomma kronan, oberoende af en kronans strandäganderätt. Enskild rätt till dessa vattenområden på grund af strandäganderätt skulle öfverhufvudtaget icke finnas, utan skulle strandfastigheternas gränser enligt denna åsikt vid en stor del af vattendragen inom laridet bestämmas af strandlinjen. Denna uppfattning har, som bekant, äfven under senaste tiden åter börjat göra sig gällande ${ }^{1}$, och har därvid uppenbarligen

1 Jmf. motiven till domarne i de s. k. Trollhättemålen, Holms Jur. Ark. 1900, s. 126 ff., och 190I, s. 419 ff., samt Åström: om svensk vattenrätt, Sthlm 1899 .

Ekonomisk Tidskrift. 1902. 
synnerlig vikt tillagts $\mathrm{I} 697$ års kvarnkommissioners instruktioner och de af dessa kommissioner fällda domar.

Man har ansett, att genom dessa kvarnkommissioner åtgärder vidtagits, som hvilade på den uppfattningen, att icke strandägaren, utan kronan på grund af det s. k. vattenregalet hade rätten till vattenområdet $\mathrm{i}$ vissa vattendrag, samt att, då dessa åtgärder skulle hafva tillkommit $\mathrm{i}$ afsikt att tillämpa och betrygga en kronans äganderätt till vattendragen, de ock med hänsyn till samma åtgärders beskaffenhet och de tidsförhállanden, under hvilka de tillkommit, måste anses vara för berörda ändamål tillfyllestgörande. Såsom stöd för den angifna åsikten, åberopas därvid, att viss kvarnkommissions domar skulle hafva konfirmerats af Carl XII, samt att riksens ständer vid riksdagen 1734 på förd klagan däröfver, att genom samma kvarnkommissions domar strandrätten förnärmades, förklarat, att vid de sålunda konfirmerade domarne borde förblifva ${ }^{1}$.

Det vill synas, som om härvid en väsentlig missuppfattning gjort sig gällande ej mindre med afseende å innebörden af det vattenregale, som i Sverige varit kronan tillerkändt, och af ändamålet med kvarnkommissionernas verksamhet, än äfven i fråga om det område, till hvilket kvarnkommissionernas verksamhet öfverhufvudtaget skulle sträcka sig. Det är emellertid blott denna sista fråga, som i denna uppsats skall göras till föremål för en något närmare undersökning, hvilken torde få anses väl behöflig, då den hittills föreliggande utredningen angående de kvarnkommissioner, som här afses, är i väsentliga afseenden ofullständig och felaktig. Redan en dylik undersökning, synes ock kunna vara af ej ringa betydelse för bedömandet af, om man från de af kvarnkommissionerna vidtagna åtgärderna verkligen kan vara berättigad att hemta stöd för antagandet af en kronans äganderätt till särskilda vattendrag.

Första uppslaget till frågan om anordnande af särskilda kvarnkommissioner, är att söka $\mathrm{i}$ ett underdånigt memorial den I 5 augusti 1695 af Landshöfdingen i Skaraborgs län Baron Harald

${ }^{1}$ I motiveringen till häradsrättens dom i Trollhättemålen synes synnerlig vikt hafva lagts på angifna omständigheter. Domen fastställdes, hvad angår förevarande fråga, utan meningsskiljaktighet af hofrätten och högsta domstolen. 
Strömfelt ${ }^{1}$. Närmaste anledningen till Strömfelts framställning i förevarande afseende synes hafva varit ett då ifrågasatt byte mellan kronan och enskilde, därvid uti vederlag för lägenheter och kronohemman några frälsekvarnar, hvilka voro belägna $\mathrm{i}$ de såsom allmänningsåar i Västgötalagens additament ${ }^{2}$ upptagna Lidan, Tidan och Nossan, blifvit supdragna för stor ränta», där dock Kongl. Maj:t hade »Dominium directum uti slijka ååar».

I memorialet framhålles, att vid skogskommissionerna kronans rätt till skogarne och därå gjorda olaga inkräktningar blifvit uppmärksammad enligt den bestämmelsen i instruktionen för dessa kommissioner, att urminnes häfd på allmänningsskogarne ej skulle gälla, om ej det område, för hvilket häfden åberopades, vore utmärkt med »fasta och oemotsägliga märken och rör af ålder uppsatta $^{3}$. Däremot hade sådant icke till Kongl. Maj:ts rätts bevakande blifvit iakttaget med afseende å allmänningsvatten, utan funnes åtskilliga, som vid allmänningsåarne hade hvarken land eller strand, men icke desto mindre där hade kvarnar under frälsetitel, eller som visserligen hade ägor intill åarne, men hvilkas hemman icke genom någon rågång på landet vore skilda från allmänningarne eller andra byägor, däruti Kongl. Maj:t och kronan hade del. Äganderätten till en del af dessa kvarnar hade tillkommit under de tider, då shvar och en haft tillfälle, där lägenhet varit, slika verk uppsätta, som sedermera förmedelst häfden de velat sig tillegna som deras urminnes frälserättighet ${ }^{4}$.

Memorialet, som är tämligen oklart affattadt, slutar med en hemställan, huru en slik åberopad häfd utan rå och rör kunde mer gälla i allmänningsvatten, än på allmänningsskogarne, och

1 Harald Strömfeit blef landshöfding i Skaraborgs län i jan. 1695. Förut hade han bevistat 1688 års skogskommission i samma län samt förrättat exekutionsverket af bemälte kommissions domar år I690, då han därjämte lät omrösa alla där i länet befintliga parker och allmänningar. I början af 1690-talet ledde han skogskommissionerna i Älfsborgs län, Dal och Upland. Se Stiernman, Svea och Göta höfdingaminne, I, s. 342, Sthlm 1745 .

2 Additamentet innehåller endast åtskilliga anteckningar af okänd författare.

${ }^{3}$ Så t. ex. stadgas i instruktionen för skogskommissarierna i Upland den 14 maj 1694: »kunnandes intet hemman eller torp på K. M:ts parker och allmenningar beläget, wara rådande uthan odalhank och stöör, med mindre man med fasta och oemotsäijeliga skiähl handgripeligen bewisar och förswarar, att det samma är uppå parken eller allmenningen lageligen af ålder omrösat, eller af sådane naturlige skilliemärken, som af ålder warit håldne för rätta skilliemärken, inbegrepne icke allenast till sin åker och äng, utan ock till skog ock utrymme.»

${ }^{4}$ Enligt Västgötalagen var rätten för en hvar att $\mathrm{i}$ vattenområde vid allmänningsland uppföra kvarn mycket vidsträckt. 
framhåller Strömfelt därvid, att då Kongl. Maj:t ägde grunden, och kvarninnehafvaren nyttjade allmänningsvattnet, »slika kvarnar» borde till Kongl. Maj:t eller kronan erlägga afgift eller ränta.

Memorialet synes hafva afsett endast sådana under frälsetitel innehafda kvarnar, hvilka icke lågo vid kvarninnehafvares enskilda strand, och för hvilka ej heller kunde påvisas en särskild rågång samt urminnes häfd, och frågan gällde endast, om ej för dylika kvarnar ränta eller afgift borde till kronan erläggas. Då memorialet af Kongl. Maj:t remitterades till kammarkollegium för utlåtande, finner man ock, att i remisskrifvelsen Strömfelts framställning så återgifves, att den skulle afse "hwarjehanda wattenwärk uppsatta i Wåre allmänningsåar af sådane Possessorer, som hwarken råda om land eller strandt dersammastädes; eller ock fuller kunna ega odel egor, men hafwa deras hemman ingen rågångh på landet från allmänningarne eller andre byegor, hwaruti kronan sorterar, och dock som frälse samma wärk sig willja tillägna under titul af urminnes häfd ${ }^{1}$,. Ännu åtminstone hade således den af Strömfelt väckta frågan icke den omfattning, att den ansågs beröra jämväl sådana kvarnar, som lågo vid en kvarninnehafvares enskilda strand.

Kammarkollegium förklarar sig i det infordrade utlåtandet instämma med Landshöfding Strömfelt däruti, att »Kongl. Maj:t och des Chrono lijka rätt tillkommer uthi allmännings wattn, som $i$ Skogar och Berg, dhe der inom allmänningarne ähro belägna, och at $\mathrm{i}$ föllie deraf medh dhe förre på lika sätt böhr procederas och förhafwas, som medh dhe senare». Då emellertid Strömfelt endast gjort en allmän framställning, utan att »in Specie nampngifwa dhe qwarnar och wattenwärck, som förmehnas $i$ allmännings eller publique watten och strömmar upsatte wara, och utan titul nyttias och innehafwas», hemställde kollegiet, om icke samma metod kunde användas vid undersökningen af kvarnarne, som vid "Skogsallmännings Commissionerna", så att landshöfdingen med lagmännerna, med hvilka en assessor i hofrätten kunde adjungeras, skulle anställa undersökning, »i anledning af dhe Instruktioner, som för Skogs Commissionen blifwit uthfärdade, och saken

1 Anmärkningsvärdt är, att detta Kongl. bref är dateradt å samma plats, Höjentorp, som Strömfelts memorial, och endast två dagar senare än detta. 
sedan medh domb afhielpa ". - Af utlåtandet framgår, att ej heller kammarkollegiet uppfattat framställningen såsom afseende vid enskild strand liggande kvarnar, utan att det tänkt sig, att den nu ifrågasatta särskilda undersökningen skulle omfatta allenast vattnen inom allmänningarne samt verkställas i hufvudsak på samma sätt, som $\mathrm{i}$ fråga om skogarne å allmänningarne iakttagits.

I anledning af ny remiss af ärendet sammanträdde därefter kammarkollegium och Kongl. reduktionskommissionen i början af år I696 till öfverläggning angående Strömfelts memorial; och vid detta sammanträde var äfven Strömfelt närvarande, Vid sammanträdet förekom en liflig diskussion, och under denna framkastades ock den frågan, om en frälseman, som hade kvarn i de uti memorialet afsedda strömmar, borde erlägga någon afgift, fastän han hade land därintill. - Sammanträdet upplöstes utan att några beslut fattades, men vid förnyadt sammanträde af Kongl. kommissionen förklarade kommissionens ledamöter sig anse, ratt den, som redan har bygt antingen på sine hemmans ägor som stöta 'in till strömmen, eller ock har omrösadt land, som qvarnen är bygd på och har derpå urminnes häfd; bör efter lag samt Kongl. Maj:ts egna förklaringar vara fri för afgift deraf, _ - _ men der man har qvarn allenast $\mathrm{i}$ allmänningsströmmen utan att ega land derintill, den kan icke för taxation och afgift frikallas, fast han har urminnes häfd derpå.»

Mot slutet af I696 inkom Landshöfding Strömfelt ånyo med en underdånig påminnelse angående den af honom väckta frågan och bifogade därvid ett förslag till instruktion för den kommission, som kunde blifva förordnad att verkställa undersökningen angående kvarnarne. Förslaget remitterades till kammarkollegium och reduktionskommissionen, hvilka företogo ärendet till behandling. Sedan därvid protokollet för kollegiets och reduktionskommissionens nyssberörda sammanträden blifvit uppläst samt däraf särskildt det ofvan angifna resultatet af de då hållna öfverläggningarne inhämtats, blef Strömfelts förslag till instruktion punkt för punkt föredraget och godkändt. I öfverensstämmelse med det sålunda fattade beslutet afläts därefter af den Kongl. kommissionen till konungen en skrifvelse, däri hemställdes, att den föreslagna instruktionen skulle af konungen godkännas och utfärdas. 
Kammarkollegiets och reduktionskommissionens betänkande öfversändes till Strömfelt med befallning att inkomma med yttrande, om han hade något vidare att påminna $\mathrm{i}$ anledning af detsamma, och anmärkte Strömfelt i sitt svar på denna remiss, att han läst igenom betänkandet och funnit, att kammarkollegium och reduktionskommissionen till alla delar gillat, hvad han föreslagit, samt förklarade sig icke hafva något att ändra i projektet. Den I 3 april 1697 utfärdades därefter instruktion för en kvarnkommission i Skaraborgs län ${ }^{1}$; och öfverensstämde denna

1 Instruktionen är till de delar, som äro af intresse för det $\mathrm{i}$ denna uppsats behandlade ämne, af följande lydelse:

"Hans högstsahl. Kongl. Maij:tt Kongl. Maij:ts högstelskelige Herr fader glorwyrdigste $\mathrm{i}$ åminnelsse har fuller af en särdeles tillförordnat Commission allaredan för detta uthi Skaraborgz lähn låtit ransaka och dömma om skogarnes natur och egenskap därsammastädes, hwilcka nembl. af dem för Kongl. M:tz parker sampt Crono och allmänningzskogar böre ansees, och dem ifrån andre private skogar och ägendom låtit omrösa och terminera; men emädan samma Commission icke är förekommit med hwad rätt dels privati sig tillägna de publique strömmarne, hwilcka äfwenwähl i Wästgiöta Lagens fragmentis eller additament upföres wara allmänningzwattn, Tyan, Lyan och Noos, uti hwilka Kongl. Maij:tz höga rätt icke mindre verserar än uthi den publique ägendomen på Landet; så är jemwähl sådant oafgiordt lämnadt; Dock som ingen privat med skiähl kan tillägna sig det som publico af ålder har warit tillhörigt, uthan skiählig afgifft därutaf till Kongl. Maij:tt och Cronan särdeles som uthi $\mathrm{I} 282$ åhrs beslut förmäles, det ingen warit berättigad at bygga $\mathrm{i}$ dhe publique wattn och strömmar, sampt dem bruka, uthan att gifwa därföre Skatt till Kongl. Maij:tt och Cronan, hwilket doch i sanma beslut förmähles Kongl. Maij:tt och Cronan till skada wara skedt uthan skatt, och ännu innehafwes; altså och på det hwar och een, som uthi allmänningzåerne i Skaraborgz lähn hafwa qwarnbyggnader, måge blifwa hörde, medh hwad rätt de antingen genom kiöp eller byte med Cronan sådan ägendom sig hafwa förwärfwat och besittia; Ty har Kongl. Maij:tt i nåder för gådt funnit att förordna Landzhöfdingen med LandzCammereraren och Häradzhöfdingarne hwar i sin Jurisdiction uthi wederbörandes närwaru att anställa en laga ransakning öfwer berörde måhl, sampt med dommar åtskillia och bijbehålla Kongl. Maij:tz och Cronones höga rätt ifrån det som Kongl. Maij:tz trogne undersåtare med fulla skiähl och bewijs sig förmå tillägna. - - _ -

I. Såsom uthi lagen besynnerligen dhe äldre tijderne finnes infördt, huruledes privati emoth afgifft hafwa kunnat förwärfwa sigh någon enskijlt rättigheet på allmänningarne till ett wist afmärckt uthrymme; hafwandes i anledning däraf hans högst Sahl. Kongl. Maij:tz högst ällskel. Herr Fader glorwyrdigst i åminnelsse utj Instructionerne för Skogz Commissionerne förordnat, att där någon icke allenast till åker och äng, uthan ock till uthägerne kunde wijsa laglige af ållder upsatte märcken och rågångar till sin prætenderade uhrminnes häfd och ägendom på dhe publique Skogarne; Så skulle han därwid blifwa orubbad; Altså will Kongl. Maij:tt härmed $\mathrm{i}$ nåder hafwa förklarat att så wijda wid undersökiandet om qwarnebyggnaderne, någon skulle kunna upwijsa en af ålder laglig och odisputerlig Rågång, som inbegriper icke allenast landtägorne, uthan och wattnet, uthi hwilcket qwarnen nyttias, Så skall densamma sådan sin rättighet alt framgeent få till godo åthniuta, så frampt han icke framdeles af annan grund blifwer utj samma egendom graverat.

2. Emädan på ett sådant sätt uhrminnes häfden med laga och oemotsäijelige märcken är tillåten uthi förre allmänningz- osh Skogz-Commissionennes Instructionnr; Ty kan den som hwarcken äger land, Strand, eller wattn, mindre har att upwijsa någre laglige märcken, med intet skiähl påstå förmedelst häfden att wara berättigad till någon eenskylt 
instruktion $\mathrm{i}$ allt väsentligt med förenämnda af Strömfelt uppgjorda och af vederbörande ämbetsverk granskade projekt. Endast några smärre, rent formella ändringar hade $\mathrm{i}$ instruktionen vidtagits $\mathrm{i}$ förhållande till förslaget. Samtidigt utfärdades emellertid jämväl instruktion för kvarnkommissioner $\mathrm{i}$ öfriga län. Instruktionen för Älfsborgs län öfverensstämde närmast med den för Skaraborgs län. Äfven de öfriga instruktionerna, hvilka voro sinsemellan öfverensstämmande, anslöto sig i allt hufvudsakligt till samma instruktion. Hvad angår instruktionerna för andra län än Skaraborgs, hade de, så vidt af för mig kända handlingar framgår, icke varit påtänkta under hela tiden för förarbetena till instruktionerna, dock med det undantaget, att af Strömfelts sistberörda bref från början af 1697 synes, att Strömfelt under december månad 1696 fäst Kongl. Maj:ts uppmärksamhet på, att äfven inom Älfsborgs län kvarnar funnos, af hvilka afgift borde

egendom och rätt utj det som publico tillhörer, uthan bör een en sådan häfd ansees på det sättet wara tillkommen, som I 282 åhrs beslut förmähler, nembl. aff det at ingen har låtit sig wårda om Cronones och fisci rätt, eller därpå i rättan tijd tahlt hwilcken häfd mehra bör skattas wara kommen af olagligit tilltagande, en laga medfart; kunnandes Cronan des rätt icke betagas genom een slijk häfd, när grunden publico tillkommer; fördenskuld där någon skulle finnas som uthi de $\mathrm{i}$ Wästgiöte additamentet upförde allmenningz wattn och Strömmar hafwer någre qwarnar och bygnader, de där till Cronan intet finnes wara skattlagde, eij häller äga Land eller wattn, som ofwan bemält är, Så böre sådane qwarnar och byggnader till K. M:tt och Cronan af Commissionen skiähligen taxeras; dock så, att ägaren som har giordt onkostnad på samma qwarnar och bygnader fram för någon annan blifwer närmast emoth berörde afgifft ock ränta demsamme att underhålla och besittia.

3. Skulle Commissionen förekomma att någon Possessor af sådane upsatte qwarnar uti allmänningzwattn hwilcka icke allenast sträckia sig genom dhe afdömbde parker och allmänningar, uthan och löpa heela Skaraborgz lähn igenom, wore interesserat utj byelag medh andra hemman, och qwarne bygnaden fuller står på dess odall frälse ägor på Landet, men nyttiar icke des mindre det allmänne wattnet sampt damfästen på Crono ägor, så böre sådane lägenheeter lindrigare taxeras, eller aldeles uthrijfwas, $i$ fall dhe skulle befinnas antingen liggia andre Cronones skattlagde odallqwarnar till præjudice osh förfång, eller och i manna minne wara uptagne.

8. Skulle något förefalla, ländande till Kongl. Maij:tt och dess Cronos höga rätts i ackt tagande, som icke så egenteligen uti denne Instructionen kan wara inryckt, eller och någre Domar förekomma, hwilcka privat personer emellan äre uthfallne emoth Kongl. Maij:tz interesse, hwilcket Domaren intet rätteligen har wist ifrån privat rättighet at åtskillia; Så lemnar Kongl. Maij:tt Commissionen frijheet sig däröfwer hoos Kongl. Maij:t i underdånighet att förfråga, då Commissionen tydeligen har att upsättia dess påminnelser och betänckiande öfwer saksens beskaffheet och sedan afwackta Kongl. Maij:tz nådigste swar och resolution däröfwer. Sluteligen drager Kongl. Maij:tt till Commissionen det nådige förtroende; at den samma effter yttersta förstånd, med all dexteritet och försichtighet härutinnan således lärer sluta och` förordna, som med Kongl. förordningar och sielfwa rättwijsan må wara eenligit, samt nu och i alla tijder förswarligit». 
utgå, samt att Strömfelt då hemstält, huruvida landshöfdingen uti Älfsborgs län skulle efter instruktionen där döma om kvarnarne, eller om Strömfelt »med häradshöfdingen skulle det inrycka och samma ärenden med dom afhjälpa» .

Enligt den nu lämnade utvecklingen angående förarbetena för kvarnkommissionernas instruktioner synes uppenbart, att stor betydelse vid tolkningen af dessa instruktioner måste tilläggas den uppfattning af desamma, som kommer till uttryck i den skrifvelse af kammarkollegium och reduktionskommissionen, hvarigenom det af Strömfelt framställda förslaget tillstyrktes.

I berörda skrifvelse angifver till en början Kongl. kommissionen $\mathrm{i}$ allmänhet såsom syftet med instruktionen, »om icke med Allmännings strömmar böör på lijka sätt förfahras som medh Allmännings Skogar och parker, nembligen att en privatus, som har någon Qwarn uti Kongl. Maj:ts allmännings strömar, men intet äger Landh eller Strand, som stöter intill samma Allmännings watten, bör derföre gifwa en skiäligh Recognition till Kongl. Maj:ts och Cronan, fastän han har uhrminnes häfd derpå." I omedelbart samband härmed framhålles emellertid att, på motsvarande sätt som enligt instruktionerna för skogskommissionerna, den, som kunde äberopa urminnes häfd, och som vid undersökningen om kvarnbyggnaderna kunde uppvisa och bevisa af àlder laglig och odisputerlig rågång, som inbegrepe icke allenast landägorna, utan ock vattnet, i hvilket kvarnen nyttjades, fortfarande borde fä tillgodonjuta sin förra rättighet, så vida han icke af annan grund kunde blifva i samma egendom graverad. I anslutning till detta tillägges därefter $\mathrm{i}$ skrifvelsen, tydligen såsom en konklusion af det förut där anförda: "Och will fördenskull i anledning deraf, oförgrijpeligen tyckias, att den, som hwarcken äger Land, Strand eller Watten, eller några Laglige märcken har att uppwijsa till dee Qwarnar och fiskerijer han i Eders Kongl. Maj:tz Allmänningz Strömmar hafwer och nyttiar, intet med skiähl kan förmedelst häfden wara berättigad till någon enskillt ägendom och rätt, utj det publico tillhörer, emedan sådan häfd är, som det i Konung Magnus Ladulås tijdh A:o I 282 oprättade Beslutet uthvijser, der af tillkommen, att ingen låtit sig wårda $\mathrm{i}$ det måhl, om Cronans och Fisci Rätt, eller derpå i rättan tijdh tahlt, hwilken häfd således mehr af olagligit tilltagande än Laga med- 
fahrt skattas wara förorsakat, hvarigenom Cronones Rätt icke kan förtagas, när grunden publico tillkommer. I anseende hwartill Wij för Wår dehl oförgrijpeligen intet annat kunnat än bijfalla Landzhöfdingen Strömfeltz meningh, hwareffter han d. 2 och 3 puncten uthaf ofwantalde till Eders Kongl. Maij:tz nådigste approbation projecterade Instruction inrättat, nembl:n att der någon skulle finnas, som utj dhe allmänningz Watten och Åar, hvilka utj ett fragment effter Wästgiöta Lagen nampngifwes, hade några Qwarnar och byggnader, som eij wore till Cronan skattlagde, och icke äga Land och Watn, som ofwanförmähles, så böre sådane Qwarnar och Byggnad till Eders Kongl. Maij:tt och Cronan skiähligen af den dertill förordnade Commissionen taxeras; Dock så, att Ägaren, som Qvarnen och Byggnaden bekåstat, må wara närmast dem emot ber:de afgifft och Ränta, framför någon annan att underhålla och besittia.»

Af det anförda framgår otvifvelaktigt, att enligt förevarande skrifvelse åtgärd af kvarnkommissionen skulle vidtagas endast med afseende à kvarnar, som icke voro skattlagda, samt endast med afseende å sådana icke skattlagda kvarnar, som icke lågo vid kvarninnehafuares enskilda strand. Sådana kvarnar skulle däremot som regel taxeras, och som undantag från denna regel, upptages det fall, att kvarnlägenheten kunde försvaras genom urminnes häfd, därest den omslöts af särskild rågång. Skrifvelsen ger för öfrigt icke anledning antaga, att den uppfattning då skulle hafva öfvergifvits, som kommit till uttryck i kammarkollegiets ofvanberörda i ärendet år I 695 afgifna utlåtande, eller att frågan $\mathrm{i}$ förevarande afseende gällde allenast allmänningsvatten, „de der inom allmänningarne äro belägna ; och gränserna till dessa allmänningar hade vid skogskommissionernas undersökningar faststälts. Det fall, att viss kvarnlägenhet icke uteslutande föll, vare sig inom enskildt strandområde, eller inom allmänning eller annat område, som ansågs tillkomma kronan, synes särskildt behandladt i skrifvelsen, då där beröres och förordas den bestämmelse, som återfinnes $\mathrm{i}$ instruktionens $\ 3$.

Undersökas härefter bestämmelserna $\mathrm{i}$ kvarnkommissionens instruktioner, hvilkas I-3 företrädesvis hafva afseende å förevarande fråga, synas dessa icke skäligen tillåta annan tolkning än 
den, som gifvits desamma i merberörda Kongl. kommissionens skrifvelse.

Enligt $\$ I, jämförd med början af $₫ 2$, har stadgats, att den $\mathrm{i}$ instruktionen för undersökning af skogarne på allmänningarne meddelade bestämmelsen, att särskildt omrösad lägenhet å skogarne kunde försvaras med urminnes häfd, skulle äga tillämpning äfven med afseende å kvarnlägenhet.

Den följande §:en innehåller sedermera en direkt bestämmelse angående de kvarnar, som af kommissionen skulle skattläggas, och synes stadgandet icke skäligen kunna på annat sätt uppfattas, än att, då urminnes häfd i allmänningsvatten ej kunde tillåtas $\mathrm{i}$ vidsträcktare mån än $\mathrm{i} \mathbb{\mathrm { I }}$ af instruktionen angafs, så skulle de kvarnlägenheter taxeras, som icke lågo inom ett till enskild strand hörande område, och som ej heller, afskilda frän allmänning genom särskild rågång, kunde försvaras genom urminnes häfd enligt samma $\& I$.

I $₫ 3$ behandlas därefter, såsom ofvan nämndt det fallet, att någon kvarnlägenhet endast till en del berörde allmänning, eller annat område, till hvilket kronans rätt sträckte sig.

Kvarnkommissionernas instruktioner hafva alltså icke föreskrifvit någon åtgärd till inskränkande af deras rätt, som hade kvarnar vid egen strand och allenast begagnade det enligt de allmänna reglerna till strandfastigheten hörande vattnet; och synes vid instruktionernas utfärdande uppmärksamheten hufvudsakligen varit fästad vid att meddela bestämmelser angående skattläggning af kvarnar $\mathrm{i}$ de till kronans allmänningar hörande vattenområden.

Instruktionerna kommo emellertid icke att af alla kvarnkommissionerna inom de olika länen tillämpas på nu angifvet sätt. Landshöfding Strömfelt, som i så hög grad medverkat vid bestämmandet af instruktionernas innehåll, synes hafva tillämpat bestämmelserna ganska själfständigt, och motsvarande tillämpning tyckes hafva iakttagits i det till Skaraborgs län gränsande Älfsborgs län, som genomflöts af delvis samma vattendrag, till hvilka Skaraborgs läns kvarnkommissioner hade att sträcka sina undersökningar. Strömfelt skattlade icke blott kvarnar, som enligt ofvan framhållna uppfattning af instruktionernas bestämmelser bort af kommissionen »till Kongl. Maj:t och kronan skäligen taxeras», utan äfven kvarnar, som lågo vid kvarninnehafvarnes enskilda 
stränder, skattlades. Därjämte vidtog kommissionen äfven motsvarande åtgärder med afseende å andra vattendrag, än sådana, som $\mathrm{i}$ instruktionen för Skaraborgs län uttryckligen nämndes såsom de, till hvilka kommissionens verksamhet skulle sträcka sig. Uppenbarligen har emellertid Strömfelt själf, såsom nedan skall vidare visas, ansett, att kommissionen gått ganska fritt tillväga; eller åtminstone har han varit tveksam om det berättigade $\mathrm{i}$ särskilda af kommissionen vidtagna åtgärder.

Inom Skaraborgs län, där Strömfelt redan före instruktionernas utfärdande utsatt terminer för kvarnundersökningarnes verkställande, afslutade kvarnkommissionen sin verksamhet redan under år ı697, och samma år började ock undersökningarne inom Älfsborgs län. Det sätt, hvarpå undersökningarne under år r 697 bedrefvos, uppväckte tydligen stor ovilja och föranledde ridderskapet och adeln att vid samma års riksdag besvära sig öfver, att de oroades med undersökning angående kvarnar, äfven där tillräcklig anledning icke funnes att antaga, att vattnet, där kvarnarne lågo, vore allmänningsvatten, och anhöllo de därför, att Kongl. Maj:t ville låta en närmare förklaring afgå till landshöfdingarne angående de vatten, som af kvarnkommissionerna borde hållas för allmänningsvatten ${ }^{1}$.

Besvären ledde till en uttrycklig förklaring af kvarnkommissionernas instruktioner $\mathrm{i}$ angifna afseende. Den behandling besvären undergingo, innan Kongl. Maj:ts beslut angående desamma fattades, förtjänar en närmare undersökning, då därigenom förklaringens, som det vill synas, ej tillräckligt uppmärksammade innebörd klarare framstår.

Å den handling, som innehåller ridderskapets och adelns besvär tecknades vid de särskilda besvärspunkterna Kongl. Maj:ts öfver hvarje punkt meddelade resolution ${ }^{2}$. Emellertid remitterades besvären sedermera till kammarkollegium och reduktionskommissionen för yttrande med afseende å de särskilda be-

1 Jfr Stiernman, Riksdagars och mötens beslut, III, s. 2I50, där i ingressen till punkt 6 af res. på ridderskapets och adelns besvär förevarande besvärspunkt återgifves.

${ }^{2}$ Resolutionen vid förevarande punkt är af följande lydelse: »Ridderskapet och adeln hade intet bordt formera sig ett beswär dheröfwer, att K. M:t genom een slijk beordrat undersökning i Landzortherne wille ernå dess höga rätt och rättighet. Och som dhe Committerades förrättning $\mathrm{i}$ landzortherne är desolverat under Reductions Commissionens närmare skärskådan. Så lährer dhen hafwa tillfälle att producera sine förmeente skäl dhersammastädes som af dhe förres förrättning finer sig wara præjudicerat och förnär skedt). 
svärspunkterna af den myndighet, hvarunder de kunde anses höra. Besvären föredrogos därefter i närvaro af kammarkollegium och reduktionskommissionen, och bestämdes därvid, hvilka frågor skulle anses höra till kammarkollegium och hvilka till reduktionskommissionen. Särskilda utlåtanden angåfvos därpå af kammarkollegium den 22 december 1697 och af reduktionskommissionen den I 7 januari i 698 .

Båda dessa utlåtanden föredrogos för Kongl. Maj:t den 26 januari I698, och resolverades då angående besvärspunkterna i allmänhet. Förevarande besvärspunkt, som blifvit öfverlämnad till yttrande af reduktionskommissionen, blef dock vid det tillfället icke afgjord, då i reduktionskommissionens utlåtande angående densamma allenast anmärkts, att, då den fråga, som i nämnda punkt berördes, hörde till såväl kammarkollegium som reduktionskommissionen, betänkande borde af dem båda i förening afgifvas. Kammarkollegium och reduktionskommissionen sammanträda sedermera den 29 januari I698 till öfverläggning angående ifrågavarande besvärspunkt närmast på grund af en muntlig befallning, som af Kongl. Maj:t meddelats presidenten, riksmarskalken Grefve Johan Gabriel Stenbock. Den af den sålunda sammansatta Kongl. kommissionen beslutade skrifvelsen $\mathrm{i}$ ärendet är daterad sistnämnda dag, och hvad däri hemställes approberas enligt påteckning i skrifvelsen . den 4:de påföljande februari, samt öfverensstämmer med Kongl. Maj:ts slutliga resolution öfver 6:te punkten af ridderskapets och adelns ifrågavarande besvär. Nyssberörda skrifvelse, äfvensom de förhandlingar, som föregingo dess antagande, äro således utan allt tvifvel att hänföra till just nämnda resolution och kunna alltså tjäna till ledning för tolkningen af den autentiska förklaring af kvarnkommissionens instruktioner, som samma resolution innehåller, ehuru resolutionen öfver besvären öfverhufvudtaget och således äfven, hvad angår denna punkt, äro daterade den 26 januari ı 698, det vill säga den dag, då beslut öfver besvärspunkterna i allmänhet, men icke öfver förevarande punkt fattades ${ }^{1}$.

1 Aström, a. a., s. 46, synes ej hafva uppmärksammat, att Kongl. kommissionen sammanträdde den 29 Jan. 1698 just för att afgifva yttrande $i$ anledning af ifrågavarande besvärspunkt till ledning vid den slutliga resolutionens meddelande. Han nämner emellertid, att sammanträdet skulle vara föranledt af besvären. Frågan skulle hafva upptagits till ytterligare behandling, sedan resolution öfver besvären lämnats, "särskildt $\mathrm{i}$ anledning af den 
Vid förenämnda sammanträde, som påbörjades på förmiddagen och efter ett afbrott fortsattes på eftermiddagen, och vid hvilket äfven i staden varande landshöfdingar, särskildt inkallade, deltogo $\mathrm{i}$ öfverläggningen, synes uppfattningen angående det yttrande, som af Kongl. kommissionen borde afgifvas, till en början hafva varit ganska sväfvande.

Presidenten, Grefve Stenbock framhöll enligt protokollet genast vid sammanträdets början, att han för sin del ansåg, att man kunde tillskrifva Kongl. Maj:t: sat - - så wijda Commissionen haar öfwerlagt saaken, ock wij kunna förstå, böhr inge andra Strömmar eller watten här wijdh komma i Consideration, än dhe som $i$ Besluten eller Lagen för allmänningswattn expresse ähre förklarade». Därefter heter det $\mathrm{i}$ protokollet, att de öfriga närvarande i kommissionen voro af samma mening. Att emellertid icke härmed något kommissionens beslut förelåg, framgår uppenbart, af hvad sedermera vid sammanträdet förekom; och kan något tvifvel i detta afseende desto mindre förefinnas, som det $\mathrm{i}$ omedelbar fortsättning i protokollet nämnes, att det ,fans sedan godt att höra, de $\mathrm{i}$ staden varande landshöfdingarne $\mathrm{i}$ ärendet, och att dessa blefvo eftersände.

Grefve Stenbock framställde vidare vid sammanträdet den frảgan: "huru man skulle kunna träda till Execution af denna saaken, så länge man eij vet, hwad för Strömmar böhra för allmänne considereras"; och framhöll han därvid tillika, att i Helgeandsholmsbeslutet nämndes, hvilka vatten skulle anses för regale, samt att, om äfven tvekan funnes, om samme beslut vore autentiskt, så vore »likväl den difficulteten häfd, sedan det kom i consideration, att Kongl. Maj:t hade autoriserat samma beslut, och tillägger han härvid: »ock kan fuller kommissionen alltså för sin del icke se, att några andra vatten, under titel af konungsådra, eller annat, kan anses för allmänna och regale, än de som i samma beslut äro nämnde».

Sedan därefter en af de närvarande landshöfdingarne ytterligare anmärkt, att man stått $\mathrm{i}$ ovisshet, hvilka vatten skulle anses

inskränkta tolkning landshöfdingen i Skaraborgs län baron Harald Strömfelt gifvit begreppet allmänningså». För så vidt med Strömfelts »inskränkta tolkning») menas, att Strömfelt ansetts icke $\mathrm{i}$ tillräcklig utsträckning hafva vid kvarnkommissionsförrättningen upptagit vattnen såsom allmänningsvatten, är denna uppfattning skäligen oförklarlig, då besvären uppenbarligen föranledts just af den stränghet, hvarmed Strömfelt gått till väga. 
för allmänna, »om de vatten, som löpa igenom landsallmänningarne, eller de som navigable äro eller konungsådror skola i consideration komma", så framhåller Grefve Stenbock, att "när Kongl. Maj:t behagar förklara, hvad strömmar och vatten för allmänningsvatten och regale skola anses, så faciliteras verket mycket för kommissionen $\mathrm{i}$ orten, ty då kommer allenast om den byggnad eller de qvarnar att undersökas, som $\mathrm{i}$ sådane publique strömmar äro uppsatte, då förnämligast synes komma i consideration, huruvida urminnes häfd kan gälla i slika vatten».

Af hvad sålunda förekommit, synes framgå, att Kongl. kommissionen då tänkt sig, att dess utlåtande borde angifva de vatten, som vore att anse för allmänningsvatten, samt att kvarnkommissionens undersökning enligt de för dem meddelade instruktionerna skulle inskränkas till de sålunda bestämda vattnen.

Mellan förmiddags och eftermiddagssammanträdet har tydligen förekommit något, hvarom protokollet ej gifver upplysning, men som utöfvat inflytande på frågans vidare behandling. Uppenbarligen har tillämpligheten af Helgeandsholmsbeslutet vid bestämmandet af, hvilka vatten skulle anses för allmänningsvatten, blifvit ifrågasatt. Till eftermiddagssammanträdet har nämligen sekreteraren vid riksarkivet Sven Leijonmarck blifvit inkallad för att lämna upplysning angående nämnda beslut. En högst anmärkningsvärd ändring i Grefve Stenbocks ställning till frågan i allmänhet är ock märkbar.

Leijonmarck tillfrågades, om han hade med sig 1282 års beslut, och förklarade han sig då ej veta af, att något sådant beslut existerat, och anförde han därvid åtskilliga skäl för sin sålunda angifna åsikt ${ }^{1}$. Sedan Leijonmarck yttrat sig, tillfrågades han, om någon annan underrättelse funnes $\mathrm{i}$ arkivet, shwad Strömmar och Wattn böra för publique hållas», hvilken fråga Leijonmark besvarade nekande. Därefter förekommo enligt protokoll endast tvänne särskilda yttranden ${ }^{2}$ nämligen af ledamoten $\mathrm{i}$ reduktions-

1 Hvad Åström, a. a., s. 44, anför angående Leijonmarcks yttrande, gifver icke något intryck af hans på anförda skäl grundade bestämda förnekande, att beslutet någonsin existerat. Däremot har samma författare, då han i nära samband med återgifvandet af L:s yttrande ganska vidlyftigt anfört ett yttrande af riksantikvarien Johan Peringschiöld, icke jämväl upptagit den del af detta, som rubbat tilltron till detsamma, nemligen att han som stöd för sin åsikt åberopar sig på ett gammalt bref, som äfven det är understucket.

2 Åström, a. a., s. 44, uppgifver, att $\mathrm{i}$ anledning af Leijonmarcks anförande sett lifligt meningsutbyte förekommit». 
kommissionen, kongl. rådet, Grefve J. Gyllenborg och af Grefve Stenbock ${ }^{1}$.

Grefve Gyllenborg framhöll att, fastän särskildt allmänningsvatten ej funnes, så vore instruktionen i alla händelser riktig, i öfverensstämmelse med den gällande regeln, att den, som ägde land, ägde ock stranden; ty däraf följde, att vattnet efter ett kronan tillhörigt land borde anses tillkomma kronan, och således vore den, som hade en kvarn däri, underkastad instruktionens bestämmelser. Han framkastade emellertid i sammanhang härmed, huruvida frågan om allmänningsvatten kunde anses såsom res integra, sedan Kongl. Maj:t en gång faststält och för autentiskt erkänt det dokument, som förmälde om 1282 års beslut.

I omedelbar anslutning till detta yttrande förklarar Grefve Stenbock på anförda skäl, att han höll det mycket betänkligt att grunda någon publik förrättning på en skrift af sådan beskaffenhet, som den, hvilken innehöll berättelsen om Helgeandsholmsbeslutet, men framhöll han tillika, att därigenom minskades dock

1 Dessa yttranden äro af följande lydelse: „Hans Excell:s Greff Gyllenborg moverade, att fast än alldrig sådant besluth warit, så ähr ändå Instruction rätt ställt i det fallet, i föllje af den regeln, att den som eger Land, eger ock Strand; ty der någen haar Qwarn i een Ström, men intet Land ock Strand, der på hon bygd ähr, uthan hörer Landet Crohnan till, sa böhr wattnet som fölljer stranden effter, för Crohnans eller Publiqut ansees; effter Crohnan kan icke wara af sämbre willkohr än privati, $i$ det fallet, hwillka dher dhe äga Land och Strand, så äga dhe ock wattnet, som stöter dher intill; discourerandes Hans Excell:s dher hoos, att han icke weth om res ähr integra att nu bringa dhenne qvæstion på bahnen, sedan Kongl. Maij:tt har een gång fastställt ock för authentiqut kändt det Document som förmähler om 1282 åhrs besluth, dheruthi Allmänningz Watten ock nämbnes.

Hans Excell:s H:r Öfwerste Marskalken Grefwe Stenbock höllt mycket betänckeligit, att grunda någen publique förrättning på een sådan skrifft, som icke finnes ibland dhe publique handlingar, icke heller $\mathrm{i}$ dhe gamble Historier ock publique Stadgar och Förordningar, ähr påberopat, icke häller blifwit på trycket befordrat, $\mathrm{i}$ anseende till dhe betänckelige Conseqvencer ock dhe swåre omdömen som slijkt hoos follket förorsaka skulle, men så förminskas Kongl. Maj:ts rätt $\mathrm{i}$ dhetta fallet dher igenom intet, när man tager Saaken på dhen fothen, att Kongl. Maj:tt har högsta rätt, att förklara alla Strömmar ock Wattn för Crohnans ock Publiqve, dhe som stöta till Crohnans ägor, Parkar ock allmänningar, så långt dhe sig sträcka, sade dher hoos att han saaken fattar så, att om I 282 åhrs besluth alldrig wore till, så synes nogsampt, att Kongl. Maij:tt haar ändå mackt, ock myndigheet till att låta anställa undersökning om Watten ock Strömmar, ock synes äfwenwähl oskiähligt wara, att een som har hwarken Land eller Strand, ock har lijckwähl opsätt Qwarn på Konungens Wattn fast han haar häfd derpå eller eij; skall nyttia samma Byggnad uthan afgifft; men på andre sijdan ähr Kongl. Maij:ts Nåd ock rättwijsa så stoor, at om een har sine Säthegårdz eller hemmans ägor wed Strömmen, ock det befinnes att Qwarnen ligger på Gårdsens ägor, så kan han ock få nyttia Wattnet; Läggiandes Hans Excell:s der till, att han håller töre Konungens enskyllte Watten, der Konungen har sine Parkar, och allmänningar, så långt som dhe sig sträckia emedan så långt Konungens Landh ähr, så långt ähr hans Strand, ock Conseqventer Konungens wattn som dher intill ștöter.» 
ej Kongl. Maj:ts rätt med afseende å det fall, besvären afsågo, när man tog saken så, att Kongl. Maj:t hade rätt att förklara alla de strömmar för kronans och publika, som stötte intill kronans ägor, parker och allmänningar, sä längt de sig sträckte. Han tillade, att äfven om I 282 års beslut aldrig funnits till, så hade Kongl. Maj:t ändå rätt att låta anställa undersökning om vatten och strömmar, och syntes det äfven vara oskäligt, att den, som hade hvarken land eller strand, men ändock uppsatt kvarn i konungens vatten, skulle nyttja byggnaden utan afgift, vare sig han hade häfd därpå eller ej. Slutligen framhöll han, att han ansåge för konungens enskilda vatten, där konungen hade sina parker och allmänningar, så långt som dessa sträckte sig, emedan sä längt konungens land vore, să längt vore ock hans strand, och konsekventer konungens vatten, som stötte där intill ${ }^{1}$.

Samtliga Kongl. kommissionens ledamöter jämte närvarande landshöfdingar voro härutinnan ense med Grefve Stenbock, och beslöts att $\mathrm{i}$ öfverensstämmelse härmed skrifvelsen till Kongl. Maj:t skulle affattas. Förenämnda skrifvelse af den 29 januari I698 afläts därefter med ett yttrande $\mathrm{i}$ saken, hvilket med ett par smärre, rent formella ändringar fullständigt öfverensstämmer med det Kongl. Maj:ts beslut, som sedermera återfinnes i 6 punkten af Kongl. resolution och förklaring den 26 jan. I 698 på ridderskapets och adelns besvär vid 1697 års riksdag ${ }^{2}$, då det där heter, att » emedan Kongl. Maj:ts utfärdade instruktion för de kommitterade till undersökningen om allmänningsvatten och de deruti upsatte qvarnar är i sig sjelf klar och tydlig, förmåendes densamma, att der Kongl. Maj:t äger allmänningsland, der bör Kongl. Maj:t jäm-

1 Af Åström, a. a., återgifves Grefve Stenbocks för frågans bedömande synnerligen viktiga yttrande på det sätt, att den senare delen däraf: »ock synes äfwenwähl (af $\dot{A}$. läst: helt) oskiäligt warà etc. anföres för sig (å sid. 46); sant att de föregående punkterna i yttrandet (å sid. 44) sammandragas sålunda: „ehuru det vore 'mycket betänkligt att grunda någon publik förrättning på en sådan skrift, som icke funnes ibland de publika handlingar, icke heller i gamla historier och publika stadgar och förordningar är påberopadt, icke heller blifvit på trycket befordradt $\mathrm{i}$ anseende till de betänkliga konseqvenser och de svåra omdömen, som slikt hos folket förorsaka skulle' han likväl fattade saken så, 'att om 1282 års beslut aldrig vore till, så synes nogsamt, att Kongl. Maj:t har ändå makt och myndighet till att låta anställa undersökning om vatten och strömmar.) Att på sätt skett, sammanbinda tvenne skilda delar af yttrandet, och att låta Stenbocks obetingade medgifvande af det betänkliga i att taga berättelsen om Helgeandsholmsbeslutet för god inledas med ett sehuru», synes icke ägnadt att gifva den läsande en rätt uppfattning af yttrandets innebörd.

¿ Se Stiernman, Riksdagars och mötens beslut, III, s. $2150 \mathrm{f}$. 
väl ega vatten, hvaraf följer att de, som uti sådant vatten uppsatt några qvarnar, hvilka icke lagligen äro omrösade, eller ligga på någon frälsegårds enskildta ägor, måste ock en viss afgift till Kongl. Maj:t derför erlägga; men àter igen, der privati äga land sä hafva de utan afgift att nyttja det intill samma land stötande vattnet; blifvandes på det sättet icke allenast å ena sidan Kongl. Maj:ts höga rätt iakttagen, utan ock å andra sidan vederbörande lemnade vid nyttjandet, af hvad dem efter lag och billigheten tillkommer». Därefter framhålles i resolutionen, att ridderskapet och adeln icke hade skäl att besvära sig, när, som det heter, fortfarande $\mathrm{i}$ öfverensstämmelse med kommissionens skrifvelse af den 29 januari, "allenast instruktionen i sitt rätta förstånd tages, och af landshöfdingarne exeqveras, som förbemäldt är, utan någon vidare extension ${ }^{1}$.

Den med denna resolution gifna förklaring af kvarnkommissionernas instruktioner synes, om man tager den efter ordalydelsen, och än mer, om man ser den i den dager, hvari förarbetena till densamma ställer den, icke kunna fattas på annat sätt, än att det kvarnkommissionen gifna uppdrag att anställa undersökning angående kvarnar skulle vara begänsadt till vatten utmed de stränder, där Kongl. Maj:t hade allmänningsland. Förklaringen kan vidare ock antagas utgå från samma förutsättning, som, att döma af förhandlingarne inom Kongl. kommissionen på eftermiddagen den 29 januari, låg till grund för den af kommissionen afgifna skrifvelsen, eller att det ej funnes något kronan tillhörigt allmänningsvatten, oberoende af en kronans strandrätt, och särskildt att det $\mathrm{i}$ ingressen till instruktionen för kvarnkommissionerna omnämnda Helgeandsholmsbeslutet ej kunde tillmätas någon betydelse såsom tillerkännande kronan en särskild rätt till vissa vatten ${ }^{2}$.

${ }^{1}$ Slutet i förevarande punkt i förklaringen är af följande lydelse: „Men där ändå någon skulle förmeena sig härutinnan förnär skee, så hafver den samme at upgifwa specialem casum med alle des omständigheter iemte sine förmente skiäl, då Kongl. Maij:t wil låta därom behörigen undersökia, och sedan därutinnan förordna, hwad Kongl. Maij:t för skiäligt och rättwist pröfwandes warder.»

2 Aström, a. a., s. 46 f., synes anse, att Kongl. kommissionen till en början enat sig om, att singa andre strömmar eller vatten härvid komma $i$ konsideration än de, som i beslut eller lagen för allmänningsvatten expresse äro förklarade», samt att den därjämte senare beslutat det närmare bestämmande af allmänningsvatten, som Grefve Stenbocks slutliga yttrande innehåller. Han framhåller nämligen i omedelbar anslutning till redogörel- 
Emot den nu angifna uppfattningen, att det genom instruktionerna och 1698 års förklaring bestämda området för kvarnkommissionernas verksamhet vore så begränsadt, att det icke kunde afse skattläggning af kvarnar vid kvarninnehafvares enskilda stränder, skulle tala, att kvarnkommissionens i Skaraborgs län domar blifvit konfirmerade af Karl XII, samt att riksens ständer vid I 734 års riksdag skulle hafva förklarat, att vid de sålunda konfirmerade domarne borde förblifva. Det gäller därför att granska, om verkligen de anförda omständigheterna skulle vara af sådan beskaffenhet, att man för den skull måste frånkänna I 698 års tydliga förklaring den betydelse $\mathrm{i}$ förevarande afseende, som den annars skulle hafva haft.

Förut är framhållet, att landshöfding Strömfelt, då han tillämpade instruktionerna på ett sätt, som, enligt hvad ofvan visats, ej synes stå i öfverensstämmelse med instruktionernas innehåll, själf synes hafva ansett, att det åtminstone vore tvifvelaktigt, huruvida särskilda af kommissionen vidtagna åtgärder kunna anses berättigade, ehuru han visserligen själf angifver, att kommissionen iakttagit alla omständigheter efter instruktionen. Strömfelt lät nämligen icke omedelbart verkställa den af kvarnkommissionens domar föranledda skattläggningen, utan fann sig föranlåten att underställa de af kvarnkommissionen fällda domarne Kongl. Maj:t approbation, ehuru ett dylikt underställande af redan meddelade domar är för instruktionen okändt. I $₫ 8$ af instruktionen finnes visserligen upptagen en föreskrift om framställande af förfrågan i särskilda tvifvelaktiga fall hos Kongl. Maj:t, men tydligen var afsikten, att dylik förfrågan skulle göras före doms

sen för ifrågavarande sammanträde: „Allmänningsströmmar skulle alltså vara: I:o $\mathrm{De}$, som i beslut (Helgeandsholmsbeslutet) eller lagen (V. G. L.) äro uttryckligen för allmänningsströmmar förklarade; samt 2:0 $\mathrm{De}$, som ligga vid eller på kronans parker eller allmānningar.»

Af det ofvan anförda framgår, att, hvad kommissionen beslutat, är endast det, som i dess skrifvelse till Kongl. Maj:t återgafs, och som sedermera kom till uttryck i 1698 års förklaring öfver kvarnkommissionernas instruktioner, således det, som Å. under 2:0 upptager. Att kommissionen kan antagas till en början hafva haft en annan uppfattning, som den på grund af den vunna utredningen öfvergaf, synes icke berättiga till att upptaga jämväl den sålunda öfvergifna åsikten såsom bestämmande för, hvad kommissionen ansett böra förstås under allmänningsströmmar. - För ötrigt kan väl ock ifrågasättas det berättigade $i$ att så-

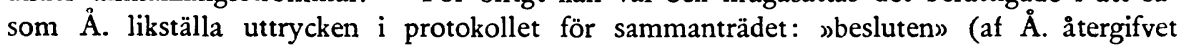
»beslut») med Helgeandsholmsbeslutet och »lagen» med Västgötalagen, eller, såsom vāl meningen får anses vara, med det $\mathrm{s}$. $\mathrm{k}$. additamentet till Västgötalagen. 
fällande, då det föreskrefs, att kommissionen hade att vid dylik förfrågan uppsätta betänkande om sakens beskaffenhet »och sedan afvakta Kongl. Maj:ts nådigste svar och resolution däröfver».

I den berättelse angående kvarnkommissionens förrättning, som Strömfelt bifogar de till Kongl. Maj:t öfversända domarne, gör han åtskilliga påminnelser och förfrågningar, berörande kommissionens verksamhet. Han framhåller därvid särskildt, att han sicke förstått, att någon $\mathrm{i}$ landsorten eller sedermera har sig öfver de fällda domar besvärat, utan varit nöjde». Detta Strömfelts påstående tages därefter för godt. Det berättigade $\mathrm{i}$ särskilda kvarnars indragande till ränta under kronan torde icke hafva blifvit föremål för någon granskning, liksom öfverhufvudtaget en särskild granskning med afseende å de olika domarne ej synes hafva förekommit. De yttranden, som i anledning af Strömfelts framställning afgifvits, äfvensom Kongl. Maj:ts svar till Strömfelt synas grunda sig på den af honom gifna berättelsen, ej på en undersökning af domarne ${ }^{1}$; och kongl. brefvet till Strömfelt $i$ ärendet utgör endast ett svar på de i samma berättelse gjorda förfrågningar och påminnelser, men innehåller icke något, som skäligen skulle kunna inverka på bedömandet af innebörden af den året förut gifna förklaringen af kvarnkommissionernas instruktioner. Genom detta Kongl. bref är det, som ofvanberörda konfirmation af kvarnkommissionens domar skulle hafva skett.

Först sedan detta Kongl. bref kommit Strömfelt till handa, skred han till verkställighet af domarne, och lät genom kronofogdarne skattlägga kvarnarne efter domarnes innehåll, hvarvid be-

${ }^{1}$ Det af kamreraren i kammarkollegium Törne afgifna, förberedande »betänkande angående den und. remonstration landshöfdingen Strömfelt inkommit med angående kvarname i Skaraborgs län», approberades af kammarkollegium och ligger till grund för kollegiets skrifvelse $\mathrm{i}$ ärendet. I detta betänkande säges angående kvarnarnes indragande till ränta under kronan endast: "Härvid har jag $i$ ödmjukhet intet annat att paiminna än så vida vederbörande med domarne varit nöjda, så maitte quarnarne derpå indragas»). - Denna del af Törnes betänkande återgifves icke af Aström, a. a., s. $5 \mathrm{I}$, där den större delen af detsamma i öfrigt upptagits.

Aström, a. st., framhåller såsom antagligt, att Kongl. Maj:ts infordrande af kammarkollegii ifrågavarande utlåtande skulle hafva berott på, att Kongl. Maj:t funnit förevarande »kommissions åtgärder i flera hänseenden otillfredsställande». Man torde hafva att anse detta för ett ytterligare uttryck för hans uppfattning, att Kongl. Maj:t ansett Strömfelts tolkning af kvarnkommissionens instruktion hafva varit alltför गinskränkt»). Jmf. ofvan s. I64 not. I. Någon som helst svårighet hade icke för honom bort möta att med ledning af Törnes betänkande taga reda på verkliga anledningen till Kongl. Maj:ts ifrågavarande remiss till kammarkollegium. 
stämdes, att kvarnspannmålen skulle betalas med allenast $3 \mathrm{dlr}$ silfvermynt tunnan. Vid befallningen till kronofogdarne är det antagligt, att Strömfelt åberopat sig på nämnda Kongl. bref, och det är förklarligt, att den uppfattningen gjorde sig gällande, att genom den s. k. konfirmationen af domarne dessa därigenom skulle hafva blifvit slutligen fastställda. Denna uppfattning återfinner man ock sedermera vid flera tillfällen såsom under behandlingen af frågan om kvarnkommissionerna vid I 734 års riksdag. Uppfattningen var emellertid säkerligen icke riktig. Kongl. brefvet afsåg icke ett fastslående af domarne såsom sådana, utan ett besvarande af Strömfelts förfrågningar för möjliggörande af de redan fällda domarnes verkställande. Detta bör man desto hellre antaga, som besvär mot ifrågavarande domar blifvit anförda och af vederbörande myndigheter behandlats, samt äfven af Kongl. Maj:t pröfvats efter den s. k. konfirmationen af domarne. Med afseende å dylika besvär kan särskildt anmärkas, att i ett fall besvären hos Kongl. Maj:t anförts så tidigt, att Kongl. Maj:t redan den 6 december 1697 remitterat dem till reduktionskommissionen, således i själfva verket före Strömfelts skrifvelse, i hvilken han uppgifver, att alla varit nöjde med domarne. Från reduktionskommissionen, hvars bref till Kongl. Maj:t i ärendet är från början af år I 700, afgår bref till landshöfding Strömfelt den 23 juli I 700 med anmodan till honom att låta anstå med exekutionen $i$ fråga om berörda kvarnar, till dess Kongl. Maj:ts beslut fallit. Strömfelt föreskrifver $\mathrm{i}$ anledning däraf genom bref till vederbörande, att tills vidare den ränta, som pålagts de kvarnar, besvären rörde, ej skulle uttagas. Han har alltså här på anmodan af reduktionskommissionen låtit inställa uttagandet af ränta, bestämd genom en af de domar, som året förut skulle hafva af konungen konfirmerats. Detta torde få anses tillräckligt styrka, att ej ens Strömfelt ansett de särskilda domarne genom den s. k. konfirmationen af Kongl. Maj:t fastställda. Besvären ledde för öfrigt till, att, sedan de ändtligen mot midten af i 7oo-talet slutligen af Kongl. Maj:t afgjorts, domen med afseende å en af de skattlagda kvarnarne upphäfdes, och kvarnägaren befriades från den ränta kvarnkommissionen år 1697 åsatt denna, utan att det finnes det minsta, som antyder, att detta Kongl. Maj:ts beslut 
skulle hafva inneburit någon ändring af ett Kongl. Maj:ts föregående beslut.

Hvad härefter angår, att riksens ständer vid I 734 års riksdag skulle hafva förklarat, att vid ifrågavarande domar borde förblifva $^{1}$, förhåller sig därmed på följande sätt ${ }^{2}$.

Anledningen till, att ständerna kommo att behandla förevarande fråga, var en af Öfversten Baron Conrad Sparre vid riksdagen gjord framställning, däri han sökte visa, att ägare af frälsekvarnar, belägna vid åarne Tidan, Lidan och Nossan, och genom 1697 års kvarnkommission lagda till årlig skatt och ränta, icke af kvarnkommissionen fått tillgodonjuta den rätt, som tillkom dem enligt allmänna lagen och kvarnkommissionens instruktion. Hufvudsakligen framhöll han därvid, att det antagandet ej vore riktigt, att förenämnda vattendrag borde betraktas såsom allmänningsvatten på grund af Helgeandsholmsbeslutet, eller på grund däraf, att de funnos upptagna $i$ additamentet till Västgötalagen. Han förmenar, "att undersåtarne $\mathrm{i}$ Vestergötland ej hafva kunnat underkastas någon annan lag eller annat medfarande än andra , och han anhåller å ägna och öfriga intressenters vägnar att »denne Provinciens inwånare, eij högre måtte blifwa belastade, än som alla andra». - Ärendet förekom vid riksdagen till förberedande behandling inom justitie-deputationen och kammar-, ekonomi- och kommers-deputationen, och upplysningar inhämtades före ärendets afgörande inom dessa deputationer från såväl kammarkollegium som kanslikollegium. Beträffande det från kammarkollegium infordrade yttrandet kan vara att märka, att det skulle afgifvas inom 8 dagar, samt att i detsamma åberopas den knappa tiden

${ }^{1}$ Med afseende å kvarnkommissionernas domar i allmänhet kan anmärkas, att genom resolutionen den 8 jan. I 723 på ridderskapets och adelns besvär år 1719 förklarats, att om kvarnkommissionerna $\mathrm{i}$ en eller annan måtto skulle hafva gjort ridd. och adeln förnär, så ägde de att till återvinnande af det, som kunde vara dem olagligen athändt, på vederbörlig ort inkomma och visa, hvad de kunde hafva att andraga mot berörda kommissioners utslag.

2 Åström, a. a., s. 45, nämner, att vid 1734 års riksdag förslag skulle hafva väckts om annullerande af Helgeandsholmsbeslutet, och att detta beslut vid samma riksdag af de tre ofrälse stånden konfirmerats. - Häremot kan anmärkas, att något förslag om beslutets annullerande af riksdagen icke väcktes, ehuru visserligen en omedelbart återtagen dylik framställning hos R. och A. förekom, och att beslutet ej heller af de tre ofrälse stånden konfirmerats. Såsom härefter skall visas, var det blott ett stånd, prästeståndet, som till en början uttalade sig för, att Helgeandsholmsbeslutet borde tillerkännas giltighet, och i de särskilda ståndens slutliga beslut angående den fråga, som föranledde detta prästeståndets yttrande, har icke något af de ofrälse stånden uttalat sig angående Helgeandsholmsbeslutet 
för svars afgifvande. Man finner ock, att kammarkollegium visserligen låtit sig föreläsas protokollen för I696 - för de sammanträden, hvilka föregingo antagandet af $\mathrm{i} 697$ års kvarnkommissionsinstruktion - men däremot icke undersökt, hvad som förekom i sammanhang med utfärdandet af 1698 års förklaring å instruktionerna. Kammarkollegiets utlåtande är ock, enligt protokollet, mycket obestämdt, och framhålles däri egentligen, att, då svåra påföljder för Kongl. Maj:t och kronan däraf skulle följa, om I 282 års besluts riktighet skulle sättas $\mathrm{i}$ tvifvelsmål och disputeras, kollegiet önskade, att saken måtte med all varsamhet handteras.

Det af justitie-deputationen afgifna utlåtandet, hvilket af kammar-ekonomi- och kommers-deputationen »efter det nogaste skärskådande och öfvervägande ${ }^{2}$ till alla delar gillades, är ganska omfattande, och däri bestrides på åtskilliga skäl giltigheten af Helgeandsholmsbeslutet, äfvensom det berättigade $i$ att anse vissa åar för kronans allmänningsvatten, därför att de upptagas såsom allmänningsvatten $\mathrm{i}$ additamentet till Västgötalagen ${ }^{1}$. Resultatet af den $\mathrm{i}$ utlåtandet gjorda undersökningen är, att deputationen för sin del finner "kvarnkommissionens emellan kronan och ridderskapet och adeln år 1697 fälda domar uti förbemälta åar böra vara utan all kraft och värkan, samt de kvarnar, som i följd deraf blifvit lagda till årlig skatt och ränta ifrån samma besvär alldeles befrias, sedan af vederbörande domare efter föregången noga undersökning uti vissa förordnade kronans fullmäktiges närvaro blifvit pröfvadt och befunnet, att kvarnen verkligen är byggd på någon privati egor». Det föreslås således en ny undersökning, vid hvilken den enskilde strandägarens rätt till vattnet skulle behörigen beaktas.

Vid behandlingen af frågan inom stånden ansluter sig ridderskapet och adeln till den i betänkandet uttalade mening. De öfriga stånden förklara däremot, att de ansågo det vara bäst att låta förblifva vid kvarnkommissionens domar. Prästeståndet framhåller härvid

1 Af det $\mathrm{i}$ många afseenden intressanta utlåtandet kan vara att märka det $\mathrm{i}$ detsamma uttalade omdömet om, i hvad mån Helgeandsholmbeslutet faktiskt blifvit tillämpadt. Det säges, att berättelsen om Helgeandsholmsbeslutet ej kan hafva någon trovärdighet, "så mycket mindre, som undersåtarne ifrån Konung Magnii Regering till närwarande tid oqwaldt besutit deras egendomar, som de ägt och ännu innehafwa uti strömarne med qwarnar, Bergzbruk uti ock ifrån Wättern, Mothala till Norkiöping och Bråwijken, ifrån Hielmaren, Eskilstuna(ån?), Mählaren och till saltsiön». Alla de här nämnda vatten finnas uppräknade i berättelsen om Helgeandsholmsbeslutet. 
såsom grund för sitt beslut uttryckligen, att det ansåge de för Helgeandsholmsbeslutets giltighet anförda skäl af »fullkommelig vigts. De öfriga båda stånden upptaga ej detta motiv, ehuru deras beslut äro senare än prästeståndets, utan grunda beslutet blott på, att det är "bäst och säkrast» att låta förblifva vid de en gång afkunnade domarne.

Den utgång frågan sålunda fick hos de ofrälse stånden synes hafva väckt en viss oro. Öfverste Sparre afgaf vid ett ridderskapets och adelns sammanträde en ganska hetsig, hufvudsakligen mot prästeståndet riktad reservation, hvilken, skriftligen affattad, äfven hos de öfriga stånden af honom inlagts. Detta föranledde, att frågan upptogs till förnyad behandling hos prästeståndet, och prästeståndet frăngår, eller, som det säger, modifierar, sitt föregående beslut. Det säges i prästeståndets protokoll härom: » och som väl bemälte herr Öfverste nu andragit åtskilliga motiver, hvarmedelst han samma sin ansökning vill bestyrka, så finner prästeståndet sig däraf föranlåtet att så till vida modifiera den af den 2 dec. i detta mål gifna utlåtelsen, att egarne af samma kvarnar måge hafva frihet, att till nästa års slut deras skäl hos reduktions- och likvidationskommissionen andraga, så att ärendet må där till nästa riksdag vederbörligen kunna examineras, att då af riksens ständer slutligen afgöras». Då prästeståndet grundat sitt förra beslut på Helgeandsholmsbeslutets riktighet, innebär denna modifikation i beslutet uppenbarligen, att äfven prästeståndet slutligen varit åtminstone tveksamt, huruvida Helgeandsholmsbeslutet kunde tillerkännas giltighet. I stället för att de tre ofrälse stånden skulle hafva konfirmerat Helgeandsholmsbeslutet, är det således icke något stånd, som slutligen uttalat sig för dettas tillämplighet.

Riksens ständers beslut i frågan inhämtas af ständernas skrifvelse $i$ ärendet till Kongl. Maj:t. Sedan det $i$ ingressen angifvits, hvilket ärende skrifvelsen afser, heter det: "Detta ärendet hafwa Riksens Ständer hos sig i öfwervägande komma låtit, och ehuruväl Riksens Ständer häröfwer stadnat uti det slut, at $\mathrm{i}$ gemen låta förblifwa wid de af Högstsalig Hans Kongl. Maij:t Konung Carl den XII åhr r699 confirmerade Qwarn Commissionens Domar, så at the nu mera eij måge qwalde eller rubbade warda, dock som Riksens ständer derom eij kommit sig at för- 
ena, huruwida och på hwad sätt desse sökande, $i$ fall deras anförde beswär, som skulle Qwarn Commissionen hafwa öfwerskridit $\sin$ Jnstruction wore grundat, til sin tillständiga rätt máge blifwa förhulpne; Altså hemställa til Eder Kongl. Maij:t Riksens Ständer underdånigst, huruvida, enär ägarne af förbemelte qwarnar uppgifva Specialem casum med alla des omständigheter, jemte skiählen, förmedelst hwilcka de förmena sig wara berättigade til ändrings åtniutande uti offta bemelte Qwarn Commissions Domar, Eder Kongl. Maij:t $\mathrm{i}$ nåder skulle täckas, derom behörigen låta undersöka, och sedan derutinnan förordna, hwad Eder Kongl. Maij:t för skiähligt och rättwist pröfwandes warder.s

Häraf framgår, att ständerna visst icke, såsom i motiven till häradsrättens af Kongl. Maj:t fastställda domar i de s. k. Trollhättemålen säges, beslutit, att vid kvarnkommissionens domar borde förblifva, utan att det tvärtom af ständerna medgifvits, att förnyad pröfning finge ske. En allmän undersökning af kvarnkommissionens domar skulle visserligen icke enligt ständernas beslut företagas, men för särskilda fall kunde de intresserade fâ domarnes laglighet pröfvad. Riksens ständer ställa sig således på alldeles samma ståndpunkt, som i 1698 års förklaring i förevarande afseende är angifven; och det medgifvande att söka ändring med afseende å kvarnkommissionens domar, som riksens ständers skrifvelse innehåller, öfverensstämmer äfven till ordalagen på det närmaste med motsvarande bestämmelse $\mathrm{i}$ förklaringen ${ }^{1}$.

Huruvida sedermera klagomål anställts och $i$ anledning däraf ändring i särskilda domar skett, har jag ej haft tillfälle att undersöka. Att $\mathrm{i}$ alla händelser vederbörande myndigheter ansett, att dylik klagans anställande kunnat medföra afsevärd påföljd, synes af behandlingen af en fråga, som jag något skall beröra, då den jämväl är på visst sätt belysande, med afseende å hvad vid 1734 års riksdag i fråga om kvarnkommissionerna förekom.

Förhållandet var nämligen, att alltifrån den första skattläggningen af kvarnarne i Skaraborgs län enligt kvarnkommissionens domar hade hvarje tunna spannmål, som af kvarnarne skulle enligt domarne utgöras, beräknats till det förut omnämnda belopp, 3 dlr silfvermynt. Så hade det fortgått till år I 73 I, då spannmålen upptagits efter markegång. Detta tyckes hafva för1 Jfr ofvan sid. I69, not. I. 
orsakat en högst väsentlig ökning $i$ räntan, och $i$ anledning af denna förhöjning är det, som Öfverste Sparre å egna och andra kvarnägares vägnar, under framhållande af Kongl. Maj:ts medgifvande $\mathrm{i}$ enlighet med riksens ständers beslut vid I 734 års riksdag, att vederbörande kvarnägare ägde att få kvarnkommissionens domar pröfvade, anhåller, att den vidare verkställigheten af beslutet om förhöjning af räntan skulle få anstå, till dess Kongl. Maj:t på "inkommande remonstrationer om Qvarnarnes rätta natur och egenskap med derwid fogade skiähl och grundelige bewijs, effter sakens rätta och egentliga sammanhang däruti ett nâdigt och rättwijst slut fattat hafver».

Frågan remitterades till kammarkollegium, hvilket anser, att kvarnspannmålen äfven för de af kvarnkommissionen skattlagda kvarnarne borde betalas efter den vanliga grunden. Kollegiet anmärker emellertid därvid, att det ville synas, som om den påyrkade ränteförhöjningen varit anledningen till den framställning om ändring $\mathrm{i}$ kvarnkommissionens domar, som skett vid I 734 års riksdag, och framhåller, att det torde hända, att kvarnägarne, om de tillätes att därefter betala kvarnspannmålen efter den förut tillämpade beräkningen, skulle kunna ställas tillfreds utan att vidare yrka på någon ändring $\mathrm{i}$ kvarnkommissionens domar. Kollegiet hemställer för den skull, »om icke, så wida dessa Qvarnägare wilja läta fahra deras talan om ändring uti Qwarn-Commissionens domar, dem må tillåtas, så hädaneffter som härtills at betala den deras qwarnar af Qwarn Commissionen ålagte Spannmåhlsräntan med Tre Dahl:r Silfwermynt tunnan» ". Denna hemställan vann Kongl. Maj:ts bifall, och Kongl. brefvet $\mathrm{i}$ ärendet den 3 december 1736 öfverensstämmer med den af kammarkollegium föreslagna resolutionen ${ }^{2}$.

1 För dem, som anse, att genom kvarnkommissionens domar strandägarne verkligen frånkänts rätten till vattenområdet vid stranden, och att detta tillagts kronan, måste denna kammarkollegiets hemställan vara svår att förklara, ty nog måste det för den, som har sådan uppfattning, förefalla egendomligt, att kollegiet kunnat ens ifrågasätta, att strandägarne skulle underlăta att begagna sig af möjligheten att fă kvarnkommissions domar häfda och därmed rätten att själfva disponera vattenområdet vid stränderna sig tillerkänd endast därför, att de tillförsäkrades att slippa ifrån en ifrågasatt höjning i den ränta, som från redan anlagda kvarnar utgick.

${ }^{2}$ Konceptet till detta Kongl. bref återfinnes i riksregistraturet. Originalbrefvet är ur samlingen kongl. bref till kammarkollegium borttaget, utom sista bladet, som innehåller blott några få rader. 
Den nu gjorda undersökningen angående kvarnkommissionerna visar, att kommissionernas verksamhet öfverhufvudtaget ej skulle sträcka sig till vattenområden, som stötte intill enskildes stränder; och vid sådant förhållande kan med deras verksamhet icke hafva afsetts att betrygga en kronans äganderätt till vissa vattendrag, oberoende af en kronans strandäganderätt. Den omständigheten, att kvarnkommissionerna på vissa ställen vidtagit åtgärder äfven med afseende å kvarnar vid enskild strand och skattlagt desamma, kan icke $\mathrm{i}$ och för sig föranleda, att det till samma strand hörande vattenområdet därmed skulle hafva förklarats vara kronans egendom. Lika litet som en utan laga skäl företagen skattläggning af ett frälsehemman skulle beröfva ägaren till detsamma äganderätten till hemmanet, lika litet kunde innehafvaren af en frälsekvarn förlora äganderätten till det vattenområde, där kvarnen fanns uppsatt, därför att kvarnen utan laga skäl af en kvarnkommission skattlades. Den dom, hvarigenom kvarnen skattlades, förorsakade visserligen en inskränkning $\mathrm{i}$ den rätt strandägaren förut haft, $\mathrm{i}$ den mån dylik inskränkning af domens uttryckliga bestämmelser föranleddes, men ej vidare; och gäller detta, hvilken grund än kvarnkommissionen ansett sig hafva för skattläggningsåtgärden. - De kvarnkommissioner, hvilka sträckt sin verksamhet till områden utom de gränser, hvilka genom kvarnkommissionernas instruktioner och 1698 års förklaring bestämts, torde för öfrigt alls icke hafva afsett, att därmed en kronans äganderätt till samma områden skulle "tryggas". Deras med afseende å kvarnarne vidtagna åtgärder torde "på grund af åtgärdernas beskaffenhet och de tidsförhållanden, under hvilka de tillkommit,, icke skäligen kunna anses hafva haft något att skaffa med frågan om den enskilde strandägarens äganderätt till vattenområdet vid stranden. 